\title{
International collaboration and covid-19: what are we doing and where are we going?
}

\author{
The mixed patchwork of achievements and mis-steps in responding to covid-19 show powerful \\ nations are not living up to their commitment to solidarity and equity, argue Jesse Bump and \\ colleagues
}

T he 19 th century pandemics that followed the globalisation of commercial and military activities led to a series of sanitary conferences, at which countries agreed to fight infectious diseases by working together. ${ }^{1}$ In the nearly two centuries since the Ottoman Empire convened the initial gathering, ${ }^{2}$ formal collaboration in health has been institutionalised through the World Health Organization, founded in 1948 as the specialised agency of the United Nations and granted international responsibilities and a legal mandate over international public health matters such as the cross-border spread of disease. ${ }^{34}$

The covid-19 pandemic has once again shown the value of international cooperation and collaboration. Its importance is intuitive and widely supported. When the World Health Assembly convened in May 2020, member states

\section{KEY MESSAGES}

- Shared objectives draw nations to collaborate on international health challenges

- Poor performance against covid-19, however, reflects patterns of selfinterested nationalism that undermine WHO and other international institutions

- Although these institutions have performed reasonably well, the pandemic reveals limitations in their mandates that reflect some member states' unwillingness to fully collaborate

- Addressing these deficits in collaboration is essential to resolving global collective action challenges, including covid-19, climate change, and noncommunicable diseases

- Advance global health by ending the institutional fragmentation and budgetary manipulation that weaken WHO, strengthen its authority over trade and travel issues, and decolonise its governance passed a resolution emphasising the need for solidarity, resource redistribution, and collective action. ${ }^{5}$ Many individuals agree, and most want their countries to increase collaboration. A poll in 14 countries showed that about $60 \%$ of respondents believe that even greater international collaboration would further reduce the number of covid-19 cases. ${ }^{6}$ And in public opinion polls the European parliament found that most citizens believed that their governments should show greater solidarity in the covid-19 era. ${ }^{7}$

\section{Logic of collaboration}

The reasons for collaboration remain clear, logical, and have endured essentially unchanged from their original conceptualisation in the 1800 s. Three of the most central are as follows. Firstly, the many ties between nations create collective health risks that are difficult to manage independently. The rapid spread of SARS-CoV-2 shows the close connections between countries, and the poorly managed economic and social costs are further evidence of their shared fate. Secondly, sharing knowledge and experience accelerates learning and facilitates more rapid progress. Information and knowledge on pathogens, their transmission, the diseases they provoke, and possible interventions are all areas in which researchers and public health professionals can benefit from the experience of others. Thirdly, agreeing on rules and standards supports comparability of information, helps establish good practices, and underpins shared understanding and mutual trust. All three reasons drive nations to collaborate and are reflected in their creation of WHO, a central authority, and its World Health Assembly (WHA), which serves as a forum for countries to share information, debate issues, and take collective decisions.

Reality of collaboration in covid-19 pandemic Despite the logical imperative to collaborate and the long heritage of attempts to do so, one year into the covid-19 pandemic and transmission rages on, with nearly 100 million cases and over two million deaths by January 2021 . The ongoing devastation has raised questions about the effectiveness of international collaboration in health and shone a powerful spotlight on WHO and other multilateral agencies with interests in disease control. Member states have ordered an inquiry into WHO's response, ${ }^{8}$ and interim findings have been critical of the institution. ${ }^{9}$

Meanwhile, WHO has warned that vaccine nationalism by members states is leading to "catastrophic moral failure." One of its independent oversight committees has added that the "rising politicisation of pandemic response" is a “material impediment” to WHO's work, and has warned that WHO cannot succeed without greater collaboration by member states. ${ }^{11}$ These realities call for close scrutiny of collaboration in international health and demand fresh attention to its problems.

\section{Member states and collaboration at WHO}

If international collaboration through WHO meets with criticisms on many fronts, then the next question is why. One of WHO's most crucial responsibilities is to notify its member states about the emergence and spread of infectious diseases, and it has been criticised for reacting too slowly at the beginning of the covid-19 outbreak in Wuhan, China. ${ }^{12}{ }^{13}$ Detailed reviews of the timing are available, ${ }^{14}$ but some of WHO's initial actions seem to have been prompt. On 31 December 2019, WHO's China office picked up a media statement by the Wuhan Municipal Health Commission mentioning viral pneumonia. After seeking more information, WHO notified partners in the Global Outbreak Alert and Response Network (GOARN), which includes major public health institutes and laboratories around the world, on 2 January. Chinese officials formally reported on the viral pneumonia of unknown cause on 3 January. WHO alerted the global community through Twitter on 4 January and provided detailed information 
to all countries through the international event communication system on 5 January. ${ }^{15}$ Where there were delays, one important reason was that national governments seemed reluctant to provide information. ${ }^{16}$

WHO is a manifestation of the advantages of cooperation and collaboration, and it consistently leads member states in ways that uphold its mission to advance the highest standard of health for all. In the pandemic, WHO has shown leadership in sharing information and in co-launching the Access to COVID-19 Tools (ACT) Accelerator, a global collaboration to accelerate development and equitable access to diagnostic tests, treatments, and vaccines. ${ }^{17}$ WHO advocated for global financial solidarity by establishing the Covid-19 Solidarity Response Fund in April 2020 and the external independent WHO Foundation in May 2020. ${ }^{18} 19$ In addition, WHO has produced a wide range of technical guidance together with cost estimates for responding to the pandemic, ${ }^{20}$ decried vaccine nationalism, and exhorted its members to increase their solidarity. ${ }^{10}$

But WHO also exemplifies the reluctance of member states to fully trust one another. For example, member states do not grant WHO powers to scrutinise national data, even when they are widely questioned,,$^{2122}$ or to conduct investigations into infectious diseases if national authorities do not agree, ${ }^{23}$ or to compel participation in its initiatives. ${ }^{24}$ Despite passing a resolution on the need for solidarity in response to covid-19, many member states have chosen self-centred paths instead. Against WHO's strongest advice, vaccine nationalism has risen to the fore, with nations and regional blocks seeking to monopolise promising candidates. ${ }^{25}$ Similarly, nationalistic competition has arisen over existing medicines with the potential to benefit patients with covid-19. ${ }^{26}{ }^{27}$ Forgoing cooperation for selfishness, some nations have been slow to support the WHO organised common vaccine development pool, ${ }^{24}$ with some flatly refusing to join. ${ }^{28}$

The tensions between what member states say and do is reflected in inequalities in the international governance of health that have been exploited to weaken WHO systematically, particularly after it identified the prevailing world economic order as a major threat to health and wellbeing in its 1978 Health for All declaration. ${ }^{29}$ WHO's work on a code of marketing of breastmilk substitutes around the same time ${ }^{30}$ increased concern among major trade powers that WHO would use its health authority to curtail private industry. Starting in 1981, the US and aligned countries began interfering with WHO's budget, announcing a policy of "zero growth" to freeze the assessed contributions that underpinned its independence and reorienting its activities through earmarked funds. ${ }^{31}$ The result is a WHO shaped by nations that can pay for their own priorities. This includes the preference that WHO focus on specific diseases rather than the large social, political, and commercial determinants of health or the broad public health capacities in surveillance, preparedness, and other areas needed for pandemic prevention and management. $^{3233}$

\section{Health cooperation at other multilaterals}

As member states have constrained WHO, practical, economic, and ethical imperatives have led other multilaterals to embrace aspects of the health agenda. The World Bank, for example, has directly engaged with global infectious disease control through its pandemic emergency financing facility, supported by issuing "pandemic bonds." ${ }^{34}$ When the first pandemic bonds were sold in 2017 as a mechanism for speeding financing, coronaviruses were mentioned specifically, along with five other viruses deemed most likely to cause a pandemic. The bond offering was oversubscribed by $200 \%$, and would, the bank claimed, "channel surge funding to developing countries facing the risk of a pandemic" and "potentially save millions of lives." 35

Even before the arrival of covid-19, the bonds were controversial in health circles because of their very high payout thresholds, ${ }^{36}$ but with more expertise in finance than health, the World Bank persisted. As the covid-19 pandemic built in early 2020 many investors believed the bonds would pay out, but they did not. ${ }^{37}$ The bonds were issued in two tranches, one of which was not eligible for payout until three months after the beginning of any outbreak, and both tranches had thresholds for mortality and spread, along with a requirement for exponential growth of cases in low income countries. ${ }^{38}$ Essentially, the payout conditions required a pandemic to be well established before funds could be released, leading to wide condemnation. ${ }^{39}$ When the bonds did pay out, the allocation for each country was capped at a maximum of $\$ 15 \mathrm{~m}$ (£11m; $€ 12 \mathrm{~m})$. Too little, too late concluded many analysts. ${ }^{40}$ Plans for future pandemic bonds were quietly abandoned. ${ }^{41}$
In other cases, major UN member states have found it easier to establish new organisations with narrowly defined missions than to strengthen or broaden WHO. Both Gavi the Vaccine Alliance and the Global Fund to fight AIDS, TB, and Malaria were established in the early 2000s around health priorities reflected in their names. Both institutions have governance structures that are more inclusive and flexible than the member states model of the UN agencies, and both are focused on areas of specific agreement among major donors.

Gavi is a public-private partnership for increasing vaccine access in low income countries, including through pooled procurement and advance market commitments. ${ }^{42}$ The expectation of a vaccine for covid-19 suggested a clear role for Gavi, which co-leads the vaccine pillar of the ACT Accelerator, Covax. ${ }^{1743}$ Although Covax membership is optional, 189 countries have joined, including China, all members of the EU, and 92 low income countries. ${ }^{44}$ The Covax facility should therefore be well placed to crosssubsidise vaccines for all low income countries, but uncertainty in its terms have led some to explore independent options. ${ }^{45}$ Additionally, there are questions about whether Gavi's market focused perspective can manage the ethical and regulatory issues threatening equitable access and distribution at a time of nationalistic competition.

The Global Fund is a public-private partnership that emerged from uncertainty about how to raise and manage the unprecedented resources required to combat HIV/AIDS and disagreements about which diseases should be included and what organisation would be in charge of the funds. ${ }^{46}$ With the arrival of covid19, the Global Fund has sought to support eligible countries by allowing them to divert up to $5 \%$ of existing grants and allocating an additional $\$ 665 \mathrm{~m}$ for ad hoc requests to "reinforce the response to covid19 , mitigate the impact of the pandemic on HIV, TB, and malaria programmes, and make urgent improvements in health and community systems." ${ }^{47}$ However, covid19 reopens many questions about how global health initiatives are financed and delivered, including whether the Global Fund should be constrained to three diseases and how it should relate to WHO.

\section{Shared future}

The covid-19 pandemic painfully shows the reasons why nations are better off 
when they cooperate and collaborate in health, and also reveals the hazards of their incomplete commitment to doing so. Member states have prioritised themselves by restricting WHO from meaningful oversight of national information and endangered global health security by competing for vaccines rather than allocating them equitably. The inability to verify national data or advance its own estimates is just one of the many crucial dimensions in which WHO is prevented from maintaining the primacy of technical competence over the self-interested obfuscations of some member states. WHO's independence is compromised also through the manipulation of its budget. The patchwork of institutions active in health reflects the limited, ad hoc agreement among powerful countries. Although generally global institutions have performed well in their missions, their often limited mandates leave the world's people inadequately protected from new threats. In a pandemic, the cost is expressed in lives and livelihoods. More than 10000 people were dying daily at end of $2020,{ }^{48}$ and the world economy was forecast to lose $\$ 5$ th or more in 2020 alone. ${ }^{49}$ The imperative of finding collaborative and collective solutions-solidarity-has never been more obvious, or more urgent, for covid-19, climate change, non-communicable diseases, and the many other pressing and grave challenges that hinge on collective action.

Meaningful international collaboration is a critical part of the road ahead and calls for immediate action in three areas. Firstly, member states must end the systematic weakening of WHO-end ad hoc institutional fragmentation in global health and end budgetary manipulation. Secondly, they must support the independence of WHO-increase its core budget and build its authority over trade and travel related issues, including compulsory licensure for pharmaceuticals. Thirdly, states must uphold fairness, participation, and accountability by granting WHO powers to hold members accountable, including for overcoming deficiencies in national data, and by decolonising its governance to address the undue influence of a small number of powerful member states.

We thank Emily Coles for her help

Contributors and sources: JBB is a historian of medicine and public health who has reported widely on current global health policy. PF is a physician and public health researcher with special interest in evidence informed policy. DRH is a global public health policy consultant and has worked as an expert at the top levels of national government and internationally. The article was conceptualised jointly by JBB, PF, and DRH. JBB wrote the initial draft using inputs from $\mathrm{PF}$ and $\mathrm{DRH}$. All three authors revised and edited the article to produce a final draft. JBB is the guarantor.

Competing interests: We have read and understood BMJ policy on declaration of interests and have no relevant interests to declare.

Provenance and peer review: Commissioned; externally peer reviewed.

This article is part of a collection launched at the Prince Mahidol Awards Conference (PMAC) in January 2021. Funding for the articles, including open access fees, was provided by PMAC. The BMJ commissioned, peer reviewed, edited, and made the decision to publish these articles. David Harper and an expert panel that included PMAC advised on commissioning for the collection. Rachael Hinton and Kamran Abbasi were the lead editors for The BMJ.

Jesse B Bump, executive director ${ }^{1,2}$

Peter Friberg, professor $r^{3,4}$

David R Harper, senior consulting fellow ${ }^{5}$

${ }^{1}$ Takemi Program in International Health, Harvard TH Chan School of Public Health, USA

${ }^{2}$ Bergen Centre for Ethics and Priority Setting, University of Bergen, Norway

${ }^{3}$ Department of Public Health and Community Medicine, Sahlgrenska Academy at Gothenburg University, Gothenburg, Sweden

${ }^{4}$ Swedish Institute for Global Health Transformation, Royal Swedish Academy of Sciences, Stockholm, Sweden

${ }^{5}$ Chatham House, London, UK

Correspondence to: J B Bump

bump@hsph.harvard.edu

Check for updates

This is an Open Access article distributed in accordance with the Creative Commons Attribution Non Commercial (CC BY-NC 4.0) license, which permits others to distribute, remix, adapt, build upon this work non-commercially, and license their derivative works on different terms, provided the original work is properly cited and the use is non-commercial. See: http://creativecommons.org/ licenses/by-nc/4.0/.

\section{@() $\mathbb{Q}$ OPEN ACCESS}

1 Howard-Jones N. The scientific background of the International Sanitary Conferences, 1851-1938. World Health Organization, 1975.

2 Ersoy N, Gungor Y, Akpinar A. International sanitary conferences from the Ottoman perspective (18511938). Hygiea Int 2011;10:53-79. doi:10.3384/ hygiea.1403-8668.1110153

3 UN. The global guardian of public health. https:// www.un.org/en/sections/issues-depth/health/

4 WHO. International Health Regulations. 3rd ed. WHO, 2005

5 WHO. Covid-19 response. Seventy third World Health Assembly 2020. https://apps.who.int/gb/ebwha/ pdf_files/WHA73/A73_CONF1Rev1-en.pdf

6 Devlin K, Connaughton A. Most approve of national response to covid-19 in 14 advanced economies. PEW Research Center, 2020. https:// www.pewresearch.org/global/2020/08/27/mostapprove-of-national-response-to-covid-19-in-14advanced-economies/
7 European Parliament. Uncertainty/EU/Hope: public opinion in times of covid-19: 2020. https://www. europarl.europa.eu/at-your-service/files/be-heard/ eurobarometer/2020/public_opinion_in_the eu_in_time_of_coronavirus_crisis_2/en-covid19survey2-report.pdf

8 Coronavirus: World Health Organization members agree response probe. BBC News 2020 May 19 https://www.bbc.co.uk/news/world-52726017

9 Nebehay S. WHO pandemic review panel critical of China, WHO delays. Reuters 2021 Jan 18. euters. com/article/us-health-coronavirus-who-panel/ independent-pandemic-review-panel-critical-ofchina-who-delays-idUSKBN29N1V1

10 Schemm P, Hassan J. WHO chief warns of "catastrophic moral failure" as rich countries dominate vaccine supplies. Washington Post 2021 Jan 18. https://www.washingtonpost.com/ world/who-chief-warns-of-catastrophic-moralfailure-as-rich-countries-dominate-vaccinesupplies/2021/01/18/033644a0-5978-11eba849-6f9423a75ffd story.html.

11 Independent Oversight and Advisory Committee for the WHO Health Emergencies Programme. Interim report on WHO's response to COVID-19, January-April 2020. https://www.who.int/about/who_reform/ emergency-capacities/oversight-committee/IOACinterim-report-on-COVID-19.pdf?ua $=1$

12 Peel M, Gross A, Cookson C. WHO struggles to prove itself in the face of COVID-19. Financial Times 2020 Jul 11. https://www.ft.com/content/c2809c99-594f4649-968a-0560966c11e0

13 Hernandez J. Trump slammed the WHO over coronavirus. He's not alone. New York Times 2020 Apr 8. https://www.nytimes.com/2020/04/08/ world/asia/trump-who-coronavirus-china.html

14 Horton R. The covid-19 catastrophe: what's gone wrong and how to stop it happening again. Wiley, 2020.

15 WHO. Timeline: WHO's COVID-19 response. 2020 https://www.who.int/emergencies/diseases/novelcoronavirus-2019/interactive-timeline:

16 Associated Press. China delayed releasing coronavirus info, frustrating WHO. 2 Jun 2020. https://apnews.com/article/3c061794970661042 b18d5aeaaed9fae.

17 WHO. The access to covid-19 tools (ACT) accelerator. 2020 https://www.who.int/initiatives/act-accelerator

18 Usher AD. WHO launches crowdfund for COVID-19 response. Lancet 2020;395:1024. doi:10.1016/ S0140-6736(20)30719-4

19 WHO. WHO foundation established to support critical global health needs, 2020. https://www. who.int/news/item/27-05-2020-who-foundationestablished-to-support-critical-global-healthneeds\#: :text=The\%20World\%20Health\%20 Organization\%20provides,safe\%20and\%20 serve $\% 20$ the $\% 20$ vulnerable

20 WHO. Coronavirus disease (COVID-19) donors \& partners: WHO says thank you! 2020. https:// www.who.int/emergencies/diseases/novelcoronavirus-2019/donors-and-partners/funding.

21 Winter L. Data fog: Why some countries' coronavirus numbers do not add up. AlJazeera 2020 Jun 17. https://www.aljazeera.com/features/2020/6/17/ data-fog-why-some-countries-coronavirus-numbersdo-not-add-up

22 Stolberg SG. Trump administration strips CDC of control of coronavirus data. New York Times 2020 Jul 14. https://www.nytimes.com/2020/07/14/us/ politics/trump-cdc-coronavirus.html

23 Hernandez J. Two members of WHO team on trail of virus are denied entry to China. New York Times 2021 Jan 13. https://www.nytimes.com/2021/01/13/ world/asia/china-who-wuhan-covid.html

24 Mancini DM, Peel M. "Vaccine nationalism" delays WHO's struggling Covax scheme. Financial Times 2020 Sep 1. https://www.ft.com/content/502df70925ac-48f6-aee1-aec7ac03c759 
25 Buranyi S. 'Vaccine nationalism' stands in the way of an end to the Covid-19 crisis. Guardian, 2020 Aug 14. https://www.theguardian.com/ commentisfree/2020/aug/14/vaccine-nationalismstands-in-the-way-of-an-end-to-the-covid-19-crisis

26 US Department of Health and Human Services. Trump administration secures new supplies of remdesivir for the United States. Press release, 29 Jun 2020.

27 Tidey A. Coronavirus: EU signs EUR 63m deal to secure supplies of COVID-19 drug remdesivir. Euronews, 2020. https://www.euronews. com/2020/07/29/coronavirus-eu-signs-63m-dealto-secure-supplies-of-covid-19-drug-remdesivir

28 Taylor $\mathrm{A}$. Why vaccine nationalism is winning. Washington Post, 2020 Sep 3. https://www. washingtonpost.com/world/2020/09/03/whycoronavirus-vaccine-nationalism-is-winning/

29 WHO. Declaration of Alma-Ata. International Conference on Primary Health Care. Alma-Ata, USSR, 1978.

30 WHO. International code of marketing breast-milk substitutes. WHO, 1981.

31 WHO. Verbatim records of plenary meetings reports of committees, WHA/34/1981/ REC/2 Thirty-Fourth World Health Assembly. 1981.https://apps.who.int/iris/bitstream/ handle/10665/155680/WHA34_1981-REC-2_eng. pdf? sequence $=1$ \&isAllowed $=y$.

32 Chorev N. Restructuring neoliberalism at the World Health Organization. Rev Int Polit Econ 2013;20:62766. doi:10.1080/09692290.2012.690774

33 Vaughan JP, Mogedal S, Kruse S, Lee K, Walt G, de Wilde K. Financing the World Health Organisation: global importance of extrabudgetary funds. Health Policy 1996;35:229-45. doi:10.1016/01688510(95)00786-5
34 World Bank. World Bank group launches groundbreaking financing facility to protect poorest countries against pandemics. 2016. https://www.worldbank.org/en/news/pressrelease/2016/05/21/world-bank-group-launchesgroundbreaking-financing-facility-to-protect-poorestcountries-against-pandemics

35 World Bank. World Bank launches first-ever pandemic bonds to support $\$ 500$ million pandemic emergency financing facility. 2017. https://www.worldbank.org/ en/news/press-release/2017/06/28/world-banklaunches-first-ever-pandemic-bonds-to-support-500million-pandemic-emergency-financing-facility[

36 Brim B, Wenham C. Pandemic emergency financing facility: struggling to deliver on its innovative promise. BMJ 2019;367:15719. doi:10.1136/bmj. 15719

37 Gross A. World Bank's pandemic bonds sink as coronavirus spreads. Financial Times 2020 Feb 24. https://www.ft.com/content/70dd05ac-54d8-11ea8841-482eed0038b1

38 Vossos T, Lauerman J. Deadly virus fails to trigger world bank's pandemic bonds. Bloomberg 2020 Apr 10. https://www.bloomberg.com/news/ articles/2020-04-10/deadly-virus-fails-to-triggerworld-bank-s-pandemic-bonds

39 Erikson SL, Johnson L. Will financial innovation transform pandemic response? Lancet Infect Dis 2020;20:529-30. doi:10.1016/S14733099(20)30150-X

40 Winck B. Coronavirus triggers $\$ 133$ million worth of the World Bank's pandemic bonds, releasing aid to developing nations hammered by the outbreak. Market Insider 202010 Apr. https://markets. businessinsider.com/news/stocks/coronavirustriggers-world-bank-pandemic-bonds-release- aid-poor-nations-2020-4-1029108864?utm source $=$ markets \&utm_medium=ingest

41 Hodgson C. World Bank ditches second round of pandemic bonds. Financial Times 2020 Jul 5. https:/ www.ft.com/content/949adc20-5303-494b-9cf1 4eb4c8b6aa6b:

42 GAVI. Phase V (2021-2025). https://www.gavi.org/ our-alliance/strategy/phase-5-2021-2025

43 Berkley S. Covax explained. 2020. https://www.gavi. org/vaccineswork/covax-explained[

44 GAVI. Covax commitment agreements. 2020. https:// www.gavi.org/sites/default/files/covid/pr/COVAX CA_COIP_List_COVAX_PR_24-11.pdf

45 Guarascio F. WHO vaccine drive bedevilled by familiar question: who pays if things go wrong? Reuters 2020 Oct 15. https://www.reuters.com/article/healthcoronavirus-who-vaccine-insight/who-vaccine-drivebedevilled-by-familiar-question-who-pays-if-thingsgo-wrong-idUSKBN2701PO.

46 Copson R, Salaam T. The Global Fund to Fight AIDS, Tuberculosis, and Malaria, background and current issues. Foreign Affairs, Defense, and Trade Division, US Department of State, 2003. https://www. everycrsreport.com/files/20030127_RL31712_6d8 aac204fb47a7dffc6368c461b99953d5afa37.pdf

47 Global Fund. Covid-19 operational response. https:// www.theglobalfund.org/en/covid-19

48 WHO. Coronovirus disease dashboard. https:// covid19.who.int/

49 Dobson AP, Pimm SL, Hannah L, et al. Ecology and economics for pandemic prevention. Science 2020;369:379-81.

Cite this as: $B M J$ 2021;372:n180

http://dx.doi.org/10.1136/bmj.n180 